\title{
Core Labour Standards and FDI : Friends or Foes? The Case of Child Labour
}

\section{Sebastian Braun*}

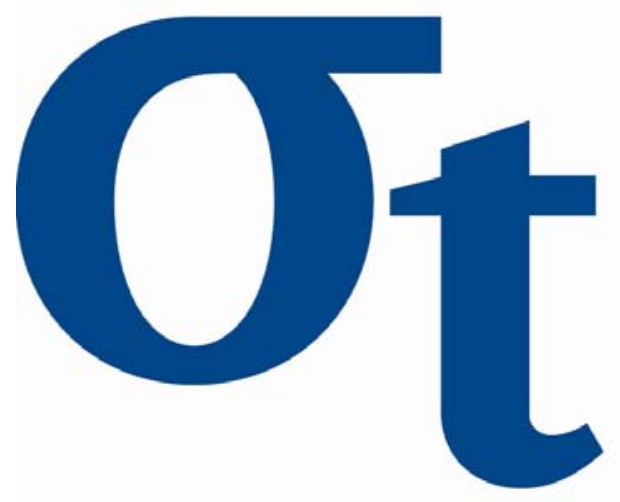

$\frac{v}{\sigma}$

* Institute for Economic Theory, Humboldt-Universität zu Berlin, Germany

This research was supported by the Deutsche Forschungsgemeinschaft through the SFB 649 "Economic Risk". 


\title{
Core Labour Standards and FDI: Friends or Foes? The Case of Child Labour
}

\author{
Sebastian Braun* \\ Humboldt University of Berlin
}

\begin{abstract}
We test the often-cited hypothesis that high levels of child labour attract foreign investors. Using panel data we show the overall effect, which child labour has on foreign direct investment (FDI), to be a (small) negative one. We find strong evidence for the theoretical prediction that child labour deters FDI by slowing down economic development. Weaker evidence is provided for our theoretical prediction that child labour can discourage FDI via its impact on the availability of a skilled labour force in an economy. The data do not indicate that high levels of child labour drive down the factor share of labour, thereby increasing the attractiveness of an economy for foreign investors.

JEL no. C33, F23, J82
\end{abstract}

Keywords: child labour, FDI, core labour standards

\footnotetext{
* The author is grateful to Michael C. Burda, Tilman Brück, Bernd Droge, Frank Kathmann, Harmen Lehment, Dennis Paschke, Juliane Scheffel, Battista Severgnini, and two anonymous referees for very helpful comments and suggestions. Martin Rama has made available some of the data used in this paper. This research was supported by the Deutsche Forschungsgemeinschaft through the SFB 649 "Economic Risk" and by the German Federal Ministry of Education and Research (project 01AK702A). All remaining errors are mine. Address: Humboldt University of Berlin, School of Business and Economics, Institute for Economic Theory II, Spandauer Straße 1, D-10099 Berlin. Email: sbraun@wiwi.hu-berlin.de.
} 


\section{Introduction}

At the beginning of the $21^{\text {st }}$ century, child labour remains a global problem of enormous proportions. According to the latest estimates of the International Labour Organisation (ILO 2002), 186.3 million children aged 5-14 are engaged in child labour. In addition, the number of child labourers aged 15-17 amounts to 59.2 million. The total number of 245.5 million implies that one out of six children is a child labourer. ${ }^{1}$ The child labour problem is particularly severe in Asia and Sub-Saharan Africa. 127.3 million or 60 per cent of all economically active children are living in the Asia-Pacific region. In this region, on average 19 per cent of the children aged 5-14 are economically active. The corresponding figure for Sub-Saharan Africa is even higher and adds up to 29 per cent. According to the World Bank (2004), in some countries, such as Mali and Bhutan, the labour force participation rate of children aged 10-14 reaches 50 per cent. Child workers therefore account for a large fraction of the total work force in many developing countries.

In the academic realm, most researchers have focused on the causes and consequences of child labour (for literature surveys see Basu 1999; Basu and Tzannatos 2003). Less attention is paid to a discussion in the international policy arena, which is related to what are commonly called core labour standards. According to the Declaration on Fundamental Principles and Rights at Work of the ILO, these standards are as follows (ILO 1998):

- the elimination of all forms of forced or compulsory labour;

- freedom of association and the effective recognition of the right to collective bargaining;

- the effective abolition of child labour; and

- the elimination of discrimination in respect of employment and occupation.

Concerns have been raised that countries might increase their (cost) competitiveness by violating one or more of these standards. In particular, so the argument goes, countries with low core labour standards might attract more foreign direct investment (FDI) and/or enjoy better export performances (for an overview of the debate see OECD 1996, 2000).

\footnotetext{
${ }^{1}$ The estimates are part of a comprehensive child labour study of the ILO (2002) and refer to the year 2000.
} 
With respect to the former type of concern, which is the focus of this paper, Rodrik (1996: 57) writes of the conventional wisdom about low-standard countries being a haven for foreign investors'. Beyond any doubt, the rapid expansion of FDI in recent years has contributed to the intensification of the debate (Kucera 2002). The FDI stock as a percentage of GDP has risen from 5.5 per cent in 1980 to 21.7 per cent in 2004 (UNCTAD 2005). In developing countries the figure is even larger with 26.4 per cent. Even though absolute FDI inflows have decreased at the beginning of the $21^{\text {st }}$ century, the long-run development provides a similar picture. Worldwide, FDI inflows add up to 648 billion US dollars in 2004 compared to 208 billions in 1990 and just 55 billions in 1980. Developing countries received FDI inflows worth 233 billion US dollars in 2004, accounting for 36 per cent of the total amount.

Amidst the growing importance of FDI inflows, the resulting competition among regions or countries to attract investors has caused concerns. While there are many location criteria of multinational firms, such as market growth or market size, which do not pose any problems, other potential determinants of FDI are more worrisome. In this regard, the level of taxation as well as labour and environmental standards have been discussed most controversially. As an example, Palley (2002) argues that competition among countries will lead to a 'race to the bottom' on labour standards. According to this line of argument, countries will subsequently water down their labour regulations and offer ever weaker standards to investors. Importantly, such a race to the bottom on labour standards does not depend on whether or not multinationals truly prefer countries with lower labour standards. 'Perception, true or false, will suffice' (Kucera 2002: 31).

As a direct result of this discussion, representatives of developed countries have frequently demanded to include binding labour standards into the framework of the World Trade Organization (WTO) in order to level the playing field. These claims are typically rejected by developing countries as hidden protectionist measures. They fear that binding standards can be used to impede foreign competition by accusing foreign firms to use, say, child labour. Disagreements in the field of international labour standards have therefore severely affected international trade rounds. Hence, 
the need for robust results on the linkages between FDI and core labour standards in general, and FDI and child labour in particular is plain enough.

Given the high policy relevance of the topic, it is rather surprising that only a few studies have so far come up with empirical evidence on the link between child labour and FDI. ${ }^{2}$ Kucera (2002) regresses FDI inflows on labour force participation rates of children aged 10-14 in a cross-country econometric model, controlling for a large set of FDI determinants. Similarly, Busse and Braun (2004) use various child labour indicators in a similar approach. In addition, Kucera (2002) also analyses the possible link between wages and child labour as lower wages might constitute the single most important factor for multinational firms to invest in countries with low labour standards. The results of the two studies are somewhat inconsistent. While Kucera (2002) concludes that the level of child labour is not an important location criterion for foreign investors, Busse and Braun (2004) find a statistically significant negative relation between child labour and FDI.

Our paper adds to the sparse literature on the linkages between child labour and FDI and refines the existing approaches by explicitly testing for all the possible theoretical linkages using panel data. This refinement is crucial because child labour can not be treated as just another determinant of FDI. In particular, there is no reason to expect child labour to be a determinant in its own right. Multinationals will not invest in a country because of its high or low level of child labour. Only if child labour has (economic) consequences relevant to the decision of the multinational firm, linkages between child labour and FDI will exist. In this regard, the use of panel data is important as we expect the economic consequences of child labour to be felt strongly over the medium- to longrun.

Therefore, adding a child labour variable to a standard FDI equation may not adequately capture the theoretical linkages. In fact, the child labour variable might act as a proxy for other unobserved country characteristics. Child labour is, for instance, closely related to human capital levels, and

\footnotetext{
${ }^{2}$ The studies considered here have also dealt with the interaction between FDI and other labour standards and/or child labour and export performance. Since the results are not relevant to the focus of this paper, they are not reported in the following.
} 
since neither Kucera (2002) nor Busse and Braun (2004) control for human capital levels in their FDI equations, their results may be driven by the correlation between child labour and human capital levels. What is needed instead is a careful empirical analysis of the linkages between child labour and FDI, which can be identified theoretically. ${ }^{3}$ This paper makes some headway in this direction.

The remainder is structured as follows. Section 2 starts by reviewing possible theoretical channels through which child labour may affect FDI. In the next, section 3, the empirical model is set up. Section 4 describes the data. The empirical results are presented in Section 5. Finally, section 6 concludes.

\section{Child Labour and FDI: Theoretical Linkages}

In this section we will discuss the theoretical effects child labour might have on FDI. By putting together the literature on the economic consequences of child labour and on the determinants of FDI, we can distinguish between three different channels, through which child labour may affect FDI decisions. ${ }^{4}$ Figure 1 provides an overview of the links identified in the following.

\subsection{Child Labour, the Wage Level and FDI}

A first possibility for child labour to affect the level of FDI is via its supposed influence on the wage level. Child labour might depress wages (relative to productivity) and can therefore be a plus for FDI. Basically two reasons have been put forward for why higher levels of child labour might result in lower wages (Kucera 2002). First of all, employers could discriminate against child labourers. Secondly, child labour can affect labour costs by increasing the supply of unskilled labour.

\footnotetext{
${ }^{3}$ In fact, Kucera (2002) addresses empirically the theoretical link between child labour and wages but does not model the other links explicitly.

${ }^{4}$ See also Kucera (2002) for a discussion of possible links between core labour standards (including the abolition of child labour) and FDI.
} 
The first line of reasoning states that employer simply pay child labourers lower wages, not reflected in lower productivity. This would generally lower wages relative to productivity in sectors affected. Evidence for this line of reasoning is presented by Anker et al. (1998). In a study on child labour in India, they find that child labourers will typically receive lower payments for the same work, if wages are paid daily. This finding is supported by Rao and Rao (1998), who ask employers in the industrial city of Visakhapatnam in India for their motives to hire child labourers. Lower labour costs rank second among the most frequently given answers. ${ }^{5}$

The discrimination argument is, however, of lower importance with respect to the attractiveness of a country to foreign investors, since it has been estimated that only few children work in the manufacturing and tradeable sectors. The ILO (2002), for instance, estimates that 8.3 per cent of all child labourers work in manufacturing. And Bachmann (2000) writes that for export-related jobs the estimates suggest a proportion of 5 per cent of the total child labour population. Hence, even if there is some wage discrimination on the enterprise level, the effect should not be felt very strongly at the country level.

A second line of reasoning argues that child labour affects the overall wage level by raising the total supply of unskilled labour. Basu and Van (1998), for example, develop a model of child labour, in which parents will send their children only to work if they are forced to do so by poverty. Assuming child and adult labour to be substitutes, the authors show that child labour can give rise to multiple equilibria on the labour market. The model economy can either end up with relatively high wages and a low level of child labour or with low wages and high child labour incidence. In the model, lower wages result from a larger supply of child labour.

Lower labour costs, which do not just reflect lower productivity, should, in turn, be important for horizontal FDI in particular. Cheap labour is considered to attract multinationals, which exploit differences in input prices by shifting some production stages to the FDI host country. Even though

\footnotetext{
${ }^{5}$ For 59.2 per cent of the respondents lower labour costs are a reason for hiring child labourers, only topped by children's suitability for the job (64.8 per cent).
} 
the empirical literature is not unambiguous, evidence for the importance of lower labour costs is presented by, for instance, Schneider and Frey (1985) and Carstensen and Toubal (2004).

\subsection{Child Labour, Human Capital and FDI}

The second potential link between child labour and FDI is via human capital. Provided that multinationals have a high demand for skilled labour, child labour should discourage FDI through its adverse effect on human capital levels. Since the labour market participation of children competes with school attendance (and proficiency), sending children to work will result in lower schooling levels and, thus, impede human capital formation. Furthermore, child labour can also inhibit human capital accumulation through other channels, for instance by damaging health.

However, the relation between child labour and human capital levels is somewhat complicated by the fact that child labour can sometimes take the form of an apprenticeship. Furthermore, a reduction in child labour does not necessarily result in a higher share of children being sent to school since especially in rural areas schools are often simply not available. Nevertheless, the overall effect child labour has on human capital is likely to be negative. Empirical studies support this view. Emerson and Souza (2004) find for Brazil that adults, who have been sent to work as children, will suffer from lower earnings. On the country level Hussain and Maskus (2003) find a negative impact of child labour on human capital formation.

The suggested negative link between child labour and human capital accumulation causes even more concerns when we introduce dynamics into the analysis. If child labourers accumulate less human capital, they will earn less money as adults. But since poverty has been identified as the most important driving force behind child labour, former child labourers are more likely to send their own children to work. Thus, child labour gives rise to a dynastic trap. Speaking with the words of Basu and Tzannatos (2003: 154), 'A Child laborer tends to grow up to have children who are child laborers by virtues of their family history.' 
A low level of human capital can be of immediate importance for FDI decisions, since multinationals can be expected to have a high demand for a skilled labour force. Investments by firms from developed countries in transition or developing countries will result in technology transfer. In the course of this innovation process, new operating schedules and job tasks will frequently arise (Bartel and Lichtenberg 1987). Since educated workers are better suited to deal with these innovations and can cope with the implementation of new technologies, multinationals can be expected to have a high demand for skilled workers. Hence, a skilled labour force should attract FDI inflows. This prediction is by and large confirmed by the empirical literature, for recent examples consult Kucera (2002) and Carstensen and Toubal (2004).

\subsection{Child Labour, Human Capital, GDP and FDI}

Finally, child labour can also depress FDI by compromising economic development through its negative impact on human capital. As seen in the previous subsection, child labour is expected to lower human capital formation. The importance of human capital for the economic development of an economy is widely acknowledged in the literature (e.g., Barro 1991, 2001). Hence, lower human capital levels are likely to result in lower levels of GDP. The interaction of child labour, human capital, and economic growth and production is analysed theoretically and empirically in Hussain and Maskus (2003). Their findings support the notion that child labour depresses growth rates and impedes economic development.

Since the market size of an economy is probably the single most important determinant of FDI (Chakrabarti 2001), this result is also highly relevant for the question of possible linkages between child labour and FDI. The size of a particular market is likely to indicate the attractiveness of a country for horizontal FDI. Almost all empirical studies on FDI determinants adopt this reasoning and include market size as an explanatory variable in their respective regressions. Even though a few papers can not identify a significant relation, the vast majority finds the link between market size and FDI to be strongly positive (e.g., Wheeler and Moody 1992; Tsai 1994; Carstensen and 
Toubal 2004). Hence, child labour should discourage FDI by its negative effect on the economic production of a country.

\section{Model Specification}

In order to capture the linkages between child labour and FDI described in the previous section, we set up a model of simultaneous equations. As a building block we use the model by Hussain and Maskus (2003). The authors develop an overlapping-generations model to analyse the relation between child labour, human capital and economic development and use the theoretical model to set up an econometric system of equations. These equations are given as follows: ${ }^{6}$

$$
\begin{array}{ll}
\text { CHILD }_{i t} & =\alpha_{0}+\alpha_{1} \text { HUMAN }_{i, t-1}+\alpha_{2} \text { QUALITY }_{i t}+u_{0 i t} \\
\text { HUMAN }_{i t} & =\beta_{0}+\beta_{1} \text { HUMAN }_{i, t-1}+\beta_{2} \text { CHILD }_{i t}+\beta_{3} \text { QUALITY }_{i t}+u_{1 i t} \\
\text { GDP }_{i t} & =\gamma_{0}+\gamma_{1} \text { HUMAN }_{i t}+u_{2 i t}
\end{array}
$$

The first equation regresses the level of child labour (denoted CHILD) on the human capital level (HUMAN) of the previous period and on school quality (QUALITY). The equation captures the idea of a (negative) linkage between human capital levels today and the level of child labour tomorrow. Higher human capital levels are likely to result in higher income, and will therefore reduce the necessity for parents to send their children to work. Furthermore, school quality affects education returns and, hence, influences schooling decisions. The second equation states that human capital is accumulated over time and current levels therefore depend on previous levels. Furthermore, human capital should also be influenced by the quality of education and by the level of child labour. However, it appears to be more appropriate to assume current human capital levels, which will be measured by average schooling years and the literacy rate of those aged 15 or above, to depend on child labour levels in the past. Hence, we modify the specification of equation (2) and

\footnotetext{
${ }^{6}$ A slight difference exists in the specification of the first equation. Hussain and Maskus (2003) also control for school costs, but the data is not available for the 1990s.
} 
regress human capital levels on lagged child labour levels. The final equation simply links human capital levels and output per capita (GDP).

In a second step, we add another two equations to account for the links between child labour and FDI. We capture the supposed relation between child labour and the wage level of an economy by means of an additional wage equation. We choose the ratio of wages to value added per worker (WVA), i.e. the factor share of labour, as the dependent variable of the equation. By normalising wages by value added, we take into account that child labour might not only affect the wage level but also average productivity. We regress WVA on lagged child labour levels as to analyse whether child labour drives down the wage share, thereby increasing profits and potentially the attractiveness of a country to foreign investors. Following Rodrik (1999) we add GDP per capita and the price level of consumption (PRICES) as additional explanatory variables. The former is included as to account for the fact that the factor share of labour might vary systematically with the level of development. Furthermore, GDP per capita might also pick up productivity changes not captured by the value added per worker. The average price level of consumption indicates differences in living costs, which are not captured by exchange-rate conversions. Finally, as in Kucera (2001) we add the urbanization rate (URBAN) as a measure for other structural aspects that might affect the wage level, such as the concentration of labour markets (Billington 1999).

Finally, we need an equation estimating FDI inflows. We regress FDI on a large number of determinants found in the literature (for surveys see, e.g., Chakrabarti 2001; Asiedu 2002). In particular, we control for market size (GDP), the skill level of the labour force (HUMAN), and the share of wages in value added (WVA) for reasons already discussed.

Furthermore, we include a number of additional explanatory variables in the FDI equation, which have typically been employed in studies on the determinants of FDI. First, market growth (GROWTH) is expected to have an influence on investment decisions. A rapidly growing economy signals high investment returns and should therefore be attractive to investors (Lim 1983). 
Another determinant, frequently used in the literature, is the openness to trade (OPEN) of the host country as measured mostly by the ratio of imports plus exports to GDP. The trade-GDP ratio is often interpreted as being a measure for trade restrictions (Asiedu 2002). The expected consequences of restrictions on FDI inflows depend on the type of foreign investment. ${ }^{7}$ Marketseeking or horizontal FDI should vary positively with trade restrictions. If obstacles exist, which impede exports to a given country, multinational firms will set up subsidiaries in the FDI host country (tariff jumping hypothesis). The existing restrictions will to some extent protect the output of foreign investors against imports of foreign competitors. Trade liberalization will reduce the benefits from foreign investments and, hence, discourage FDI inflows. Conversely, openness to trade is expected to be a positive location criterion for multinationals, which undertake exportoriented investments (vertical FDI). In this case, trade barriers simply add to the transaction costs of the investing firms and, hence, reduce the profitability of FDI.

While theoretically the impact of openness to trade on FDI remains ambiguous, the empirical evidence clearly suggests that open countries receive higher FDI inflows. Although a few studies find an insignificant relation, the vast majority concludes that a strong positive link exists (e.g., Asiedu 2002; Kucera 2002). The result is expected to be particularly strong in poor, developing countries, for which market-seeking FDI arguably plays only a minor role.

In addition, political and country risk (RISK) is often used as an explanatory variable in studies on the determinants of FDI in developing countries. Indeed, in a survey of managers of multinational firms, political stability ranked $4^{\text {th }}$ among the most important location criteria (Hatem 1997). However, the empirical evidence is mixed. While Schneider and Frey (1985) and Harms and Ursprung (2002) find the expected negative link, other authors such as Asiedu (2002) find no significant relation.

\footnotetext{
${ }^{7}$ As we consider data on total FDI inflows into a country, we are not able to distinguish between different types of FDI in our empirical analysis. When interpreting the results one has to keep in mind that the results hold for average FDI, but not necessarily for FDI undertaken for different motives and in different sectors. Some insights into these issues are provided by Daude et al. (2003). Their study analyses the interaction between FDI and core labour standards in Latin America and the Caribbean, using bilateral FDI data for the United States and Japan, which also allow for some rough industry breakdowns.
} 
We also control for the macroeconomic stability of a country (STABILITY) as it is common in the literature on FDI determinants of developing countries. Some evidence for the importance of economic stability (as measured by the inflation rate of a country) to foreign investors is presented in Harms and Ursprung (2002), while Asiedu (2002) does not find statistically significant effects.

Finally, geography plays an important role in determining FDI flows. In particular, landlocked developing countries (i.e. countries that do not have a coastline) are severely disadvantaged. While the average FDI inflows per capita to all developing countries amounted to 35 US dollars between 1992 and 2001, landlocked developing countries received only 13 US dollars per capita in the same period (UNCTAD 2003). Thus, we add a dummy variable (LLDC) to our FDI equation indicating whether or not a country is landlocked. ${ }^{8}$

In summary, we end up with the following system of equations:

$$
\begin{aligned}
& \text { CHILD }_{i t}=\alpha_{0}+\alpha_{1} \log (\text { HUMAN })_{i, t-1}+\alpha_{2} \text { QUALITY }_{i t}+u_{0 i t} \\
& \operatorname{HUMAN}_{i t}=\beta_{0}+\beta_{1} \text {HUMAN }_{i, t-1}+\beta_{2} \text { CHILD }_{i, t-1}+\beta_{3} \text { QUALITY }_{i t}+u_{1 i t} \\
& G D P_{i t} \quad=\gamma_{0}+\gamma_{1} C A P W O K_{i t}+\gamma_{2} H_{U M A N_{i t}}+u_{2 i t} \\
& W V A_{i t}=\delta_{0}+\delta_{1} \text { CHILD }_{i, t-1}+\delta_{2} G D P_{i t}+\delta_{3} \text { PRICES }_{i t}+\delta_{4} U R B A N_{i t}+u_{3 i t} \\
& F D I_{i t}=\lambda_{0}+\lambda_{1} G D P_{i t}+\lambda_{2} G R O W T H_{i t}+\lambda_{3} H U M A N_{i t}+\lambda_{4}(H U M A N)_{i t}^{2} \\
& +\lambda_{5} L_{L D C_{i}}+\lambda_{6} \text { OPEN }_{i t}+\lambda_{7} \text { RISK }_{i t}+\lambda_{8} \text { STABILITY }_{i t} \\
& +\lambda_{9} W V A_{i t}+u_{4 i t}
\end{aligned}
$$

Note that we have refined the GDP equation by adding a variable measuring physical capital per worker (denoted CAPWOK). Furthermore, we use the logarithm of human capital as an explanatory variable in the child labour equation. This essentially captures the idea that the effect of human capital on child labour diminishes with the accumulation of human capital (see Hussain and Maskus 2003). Additionally, a scatter plot between HUMAN and FDI provides some evidence that the

\footnotetext{
${ }^{8}$ Since we do not have data on bilateral FDI flows, we can not include a measure of the distance between source and host country. Moreover, our study does not focus on a specific region and the most important source countries differ considerably between countries. Thus, it does also make little sense to compute the distance of the various countries with respect to a fixed location as to account for geographic differences.
} 
relation between human capital and foreign direct investment inflows is not a linear one. Hence, we allow human capital levels to enter the FDI equation in a linear and in a quadratic form. ${ }^{9}$

In addition to the variables described above, unobserved factors might affect the results. For instance, the level of child labour in a country is likely to be influenced by the national legislation and its enforcement or by specific cultural attributes. Economic performance might depend on unobserved institutional characteristics. By not taking into account such factors, we risk an omitted variable bias. Ideally, we control for such country specific effects by time-demeaning the data or by including country dummies in each of the equations. Unfortunately, we have relatively few timeseries observations per country (3.5 on average, with a maximum of six). Hence, the inclusion of country fixed effects drastically reduces the number of degrees of freedom. ${ }^{10}$

As a compromise, we not only estimate the model with country specific fixed effects but also follow Hussain and Maskus (2003), and estimate the model using continent dummies as to save degrees of freedom and tackle the problem of unobserved effects. 'Broadly, it may be argued that countries from the same continent have experienced similar histories in terms of their colonial regimes, cultural attributes, and policy approaches' (Hussain and Maskus 2003: 1004).

Finally, unobserved effects that evolve over time, such as the world business cycle, are accounted for by including time dummies. We will estimate the model including time and cross-sectional dummies separately as well as simultaneously. This also allows us to compare the results of regressions driven by time-series and cross-sectional variation, respectively.

It is straightforward to show that each equation in the system is identified.

\section{Data Description}

\footnotetext{
${ }^{9}$ The respective scatter plot can be obtained from the author upon request.

${ }^{10}$ In fact, we have insufficient observations in order to estimate the model with country fixed effects as long as we use CHILD1 as our child labour variable. Similarly, we have to drop two parameters when we include country fixed effects and estimate the model using SCHOOL (we choose to drop PRICES and STABILITY).
} 
Our empirical study will focus on low income as well as on lower and upper middle income countries only (as classified by the World Bank 2004), ${ }^{11}$ since child labour is a problem strongly associated with the economic development of a country. The analysis will rest on data for the period 1970 to 1999 . The restriction to the time span is motivated by the availability of data. Prior to 1970 , there are no statistics on FDI inflows. On the contrary, the wage share variable is only available until 1999. Furthermore, the wage statistics are only available as averages for periods of 5 years. Hence, we also compute averages of 5 years for all the other variables included in our analysis. Averages are calculated for 1970-74, 1975-79, 1980-84, 1985-89, 1990-94 and 1995-99. ${ }^{12}$ Since FDI often oscillates strongly without changes in the underlying investment conditions, using midterm averages in the empirical study would make sense, even if data on all variables were available on a yearly basis.

The child labour incidence of a country is difficult to measure in practice and available indicators suffer from various shortcomings. As a check of robustness we will employ two alternative child labour measures. The first variable, taken from the World Bank (2004), is called CHILD and measures the labour force participation rate of children aged 10 to 14 . This measure is the one most often used in empirical research on child labour. The main problem of this indicator lies in the fact that for many countries it is based on projections and estimates rather than on reliable surveys. We will therefore follow Kucera (2002) and Busse and Braun (2004) and use the secondary school non-enrolment rates (SCHOOL) as an additional proxy for the incidence of child labour. The basic notion behind the indicator is that those children, who do not attend school, work and those, who go to school, do not work. However, children not attending schools are not necessarily child labourers. Especially in rural areas schools are often simply not available. Moreover, parents might not send their children to school due to the poor quality of education. Conversely, children may attend school but work part-time nevertheless. An additional problem is that schools may exaggerate enrolment

\footnotetext{
${ }^{11}$ Data availability further restricts the country sample. For an overview of the country included in the empirical analysis see table 1 .

${ }^{12}$ As lagged values of HUMAN and CHILD are included in our model, we also calculate the respective values prior to 1970.
} 
rates. The estimates are again taken from World Bank (2004). Data on school enrolment rates are not available prior to 1970 . Because we employ the lagged value of child labour incidence in our regression model, the analysis focuses on the period 1975-1999 whenever SCHOOL is used as an indicator of child labour.

As a measure of contemporaneous human capital levels, we mainly rely on the average years of educational attainment in the total population over age $15 .{ }^{13}$ The variable is denoted HUMAN and data is taken from Barro and Lee (2000). Since the impact, which child labour has on human capital levels, is a crucial transmission mechanism, through which child labour can affect FDI, we will also employ the literacy rate (LITERACY) as a check of robustness. The literacy rate as an indicator of human capital should be especially relevant in our context of developing countries but measures very basic skill levels only. Data comes from World Bank (2004).

Next, GDP per capita is used to measure economic development and to control for market size in the FDI equation. Data comes from the Penn World Table (Heston et al. 2002) and is measured in international dollars (i.e. PPP converted). Following Caselli (2005), we use the same data base to construct a measure of physical capital per worker (CAPWOK). The total capital stock K of an economy is calculated using the perpetual inventory equation

$$
K_{t}=I_{t}+(1-\delta) K_{t-1}
$$

where I denotes investment and $\delta$ is the depreciation rate (set to six per cent). The initial capital stock $\mathrm{K}_{0}$ is computed as $\mathrm{I}_{0} /(\mathrm{g}+\delta)$. $\mathrm{I}_{0}$ is the first available value of the investment series, while $\mathrm{g}$ denotes the geometric growth rate of investment for the period between the first year with available data and 1970. The capital stock is then divided by the total number of workers in order to obtain a measure of physical capital per worker. Further details concerning the procedure and the rationale underlying the construction of the capital data can be found in Caselli (2005).

\footnotetext{
${ }^{13}$ One possible problem of employing this indicator in our study is that it conveys information on skill levels of the overall population rather than of the workforce only. We therefore constructed a weighted version of the variable, using as weights the share of females and males in the total labour force. The regression results are very similar when using the two different versions of HUMAN. As we loose a few observations by weighting, we stick to the unweighted indicator in the following.
} 
The growth rate of GDP per capita accounts for market growth and potential in the various countries (GROWTH). As a measure for the openness to trade, we use the ratio of the sum of imports and exports divided by GDP (OPEN), while macroeconomic stability (STABILITY) is measured by the average inflation rate of a country. As an indicator for school quality, we follow Hussain and Maskus (2003) and use the pupil-teacher ratio in primary schools. All these variables come from the World Bank (2004).

The choice of the two remaining variables, namely political and country risk as well as the factor share of labour proved to be more difficult. For the former we use the two Freedom House (2004) indicators for civil liberties and political rights. The variables take into account a very broad number of human and political rights. Both indicators are measured on a scale from 1 to 7 with higher numbers indicating fewer rights. We merge both indicators into a single variable (RISK) as suggested by Helliwell (1994):

$$
\text { RISK }=\frac{14-(\text { Political Rights }+ \text { Civil Liberties })}{12}
$$

As a result, we obtain a single variable ranging from 0 (no political rights and civil liberties) to 1 (full set of political rights and civil liberties). We expect this measure to be a reasonably good measure for political and country risk, since lower rights will result in, for example, more corruption, greater state interference or weaker property rights.

A natural source for indicators related to wage costs is the Yearbook of Labour Statistics published by the ILO. However, the period covered in this publication only starts in 1980 and for the majority of countries data series begin even later. Furthermore, it is difficult to organize the data in such a way that they are easily comparable across countries and time, since many different indicators are used for different countries. A recent attempt to organize labour market data from a wide variety of sources has been undertaken by a team at the World Bank (Rama and Artecona 2002). Data are collected as averages for periods of 5 years, ranging from 1945-49 to 1995-99. 
From this database we obtain labour costs per worker in the manufacturing sector in current US dollars per year. The indicator, coming from plant-level surveys, is computed as the ratio between total compensation ${ }^{14}$ and the number of workers in the manufacturing sector as a whole. The database also contains information on the value added per worker in the manufacturing sector. The underlying data are mainly based on plant-level surveys, and figures are computed as the ratio between total value added by the manufacturing sector and the number of employees engaged in the sector as a whole. In order to obtain an estimate of the wage share, we divide labour costs by total value added per worker in the manufacturing sector. The resulting figure is a reasonable proxy for the wage share relevant to FDI decisions in developing countries, since in those countries most FDI still flows into the manufacturing sector.

When considering the wage data, one has to take into account possible shortcomings. The most important one is that the database is still work in progress, and the files for almost one third of the countries in it still need to be carefully checked for completeness and consistency. ${ }^{15}$ In spite of the limitations, the studies, which have used the database so far, have shown promising results. An example is Rodrik (1999), who uses the data set to analyse the link between democratic rights and the wage rate in a country.

As data on SCHOOL, HUMAN and QUALITY are only available in intervals of 5 years, we use linear interpolation to obtain proxies for the average over the time span in consideration. From 1990 onwards, yearly data on SCHOOL and QUALITY are available and we use these data to calculate the 5-year averages in the usual manner. The labour force participation rate of children aged 10 to 14 (CHILD) is only measured in 10-year intervals before the 1990s. In this case, we define two variables. CHILD2 again uses linear interpolation to compute 5-year averages. Since this might deliver rather imprecise proxies for the true value of CHILD over the relevant time span, we also define CHILD1, which simply uses the data for the beginning of a period to proxy the average in

\footnotetext{
14 Compensation consists of all kinds of remuneration paid directly by the employer plus all social security contributions of the employer on behalf of their employees.

${ }^{15}$ For a comprehensive overview of methods used to compile the database as well as possible problems related to it, see Rama and Artecona (2002).
} 
the subsequent time span of 5 years. Consequently, CHILD1 is only defined for 1970-74, 1980-84 and 1990-94. Quite clearly, CHILD1 has the major shortcoming that only a fraction of the dataset can be utilised in combination with this variable. When interpreting the results in the following section, one has to bear in mind the limited availability of data on child labour, in particular for the period prior to 1990 .

Table 2 summarises data definitions and data sources, while descriptive statistics can be found in table $3 .^{16}$

\section{Empirical Results}

For reasons described in section 3 and 4, we test a large number of different specifications. In particular, we use three child labour variables and estimate the model including time- and crosssectional dummies separately as well as simultaneously. Furthermore, we also check the robustness of the results by employing the literacy rate as an alternative measure of human capital levels. As the estimation method, we choose Three-Stage Least Squares (3SLS). The results of an exemplary regression are reported in table 4 . In this estimation, we use average educational attainment as a measure of human capital, CHILD2 as the child labour variable, and control for time effects by means of time dummies. Table 5 provides a complete overview of the findings of the different estimations relevant to the underlying question of this paper.

The estimation results of equation (4) provide some insights into the determinants of child labour. The results are basically in line with those found by Hussain and Maskus (2003). Not surprisingly, human capital levels have significant negative effects on the extent to which child labour exists in a country. Intuitively, a high human capital endowment results in higher earnings and, hence, children do not have to contribute to the income of the household. Furthermore, the probability that parents can afford to send their children to school is higher, if they have received a better education. However, the negative impact of an increase in human capital levels on child labour becomes

\footnotetext{
${ }^{16}$ There are no outliers in the data, which drive the results reported in the following section.
} 
smaller the higher the human capital level in an economy already is. The quality of education also has the expected positive sign and is found to be statistically significant.

To investigate, whether child labour affects FDI via lower human capital levels, we have to take a closer look at the estimations of equations (5) and (6) of our model. If there is indeed a link, two conditions must be fulfilled. First of all, child labour has to have an impact on human capital. Secondly, human capital or the availability of skilled labour must be a location criterion for multinational firms. Only if evidence for both relations is found, a link between child labour and FDI via human capital levels can be established.

The outcome is unambiguous for the relation between (past levels of) child labour and human capital. The relevant coefficient is negative and highly statistically significant. As shown in column (5) of table 5, the result is found across the different specifications. Hence, a high level of child labour today impedes tomorrow's human capital accumulation of an economy. However, the empirical evidence is less clear-cut with respect to the effect human capital levels have on FDI inflows. In our example regression, we find the coefficient of the linear human capital term to be negative, while the coefficient on the squared term is positive. Yet both variables are not statistically significant in the specific regression.

Table 5 reveals that we do find some statistically significant evidence for a positive relation between FDI and squared human capital levels when child labour levels are measured in terms of CHILD1 or SCHOOL (and therefore somewhat different sub-samples are utilised). This finding suggests that the positive effect of skill levels on FDI is accelerating with the accumulation of human capital. We also find (somewhat weaker) evidence for the statistical significance of a negative link between linear human capital levels and FDI in some of the specifications. Taken together, these results would imply that increases in skill levels have a negative impact on FDI inflows when starting at low initial levels. With the accumulation of skills the negative effect then vanishes and eventually becomes positive. The positive impact of a marginal increase in the human capital level is greater the more human capital has been accumulated in the past. A possible 
interpretation of this result is that multinationals, which invest in developing countries, either demand cheap but low-skilled workers or really well-trained employees.

However, the regression result concerning the link between skill levels and FDI inflows is not robust across the different specifications. In particular, we do not find any statistically significant estimates when we include country fixed effects in the estimation. In the regressions employing literacy rates as an indicator of human capital, we even find the sign of the coefficients on the linear and squared human capital term to be reversed (and not statistically significant). When using the literacy rate in this context one has to bear in mind that it only measures the prevalence of very basic skills in the population.

In a next step, we examine the estimation results with respect to the suspected link between child labour, human capital, GDP and FDI. Therefore, we have to take a closer look on three different links. First of all, we have already found evidence for a negative link between child labour and human capital. Secondly, the estimation of equation (6) sheds some light on the question of whether or not human capital levels affect GDP. In all but one regression, human capital is found to be a statistically significant positive determinant of GDP. Hence, similar to Hussain and Maskus (2003) we find that child labour has indeed a detrimental effect on the economic performance of a country due to its adverse effect on human capital formation. Finally, the estimation of equation (8) shows that GDP is an important FDI determinant, a fact well documented in the literature. Again, this result is unambiguous as GDP has been found to be positive in all estimations and to be statistically significant in the vast majority. In summary, strong evidence is provided for a negative link between child labour and FDI through the effect the former has on the economic development of a country. This finding is not affected by the specification chosen.

The final possible link between child labour and FDI is via an impact on the factor share of labour. The coefficient on the child labour variable in the wage share equation of our exemplary regression is positive but not statistically significant. Even though the expected negative coefficient is found in most of the other specifications, the impact of child labour on wage shares remains largely 
statistically insignificant across the different specifications. This result is in line with the finding of Kucera (2001), who also do not detect any statistically significant influence of child labour on wage shares. Moreover, we do not find any evidence for the hypothesis that lower factor shares of labour boost FDI inflows. In fact, we find both positive and negative coefficients on WVA in the FDI equation but the standard errors are far too large for any statistical significance of the results. Importantly, in none of the specifications a statistically significant (negative) impact of child labour on the factor share of labour and a significant (positive) effect of lower wage shares on FDI is established. Therefore, the empirical results clearly indicate that child labour has no positive effect on FDI in developing countries by driving down the ratio of wages to value added.

The overall evidence suggests that child labour does not boost FDI but is even likely to depress investment inflows somewhat. Most likely the effect is transmitted via the effects child labour has on the economic development of a country. With the exception of the link between human capital levels and FDI, the empirical findings are rather robust to the choice of the various specifications. ${ }^{17}$

To get an impression of the magnitude implied by our estimates we have calculated the overall impact on FDI inflows tomorrow of an increase in today's child labour level by 1 per cent. In the calculation, we take only statistically significant values into account and evaluate the human capital effect at the sample mean. The result for each specification is reported in column (12) of table 5 . Typically, the overall effect is negative and small. For our exemplary regression, for instance, a value of -0.0024 has been computed. When relating this value to the average per capita FDI of the countries in our sample, we find that an increase in the child labour variable by 1 per cent will depress FDI inflows per capita by 0.02 per cent. Higher negative values are calculated in particular when we do find an additional impact of skill levels on FDI. Such an effect is, for instance,

\footnotetext{
${ }^{17}$ The findings could potentially be affected by multicollinearity between human capital levels and GDP per capita, which would complicate the distinction between the two negative channels through which child labour can affect FDI. However, the partial correlation between HUMAN and GDP lies between 0.656 and 0.673 (depending on the subsample utilised in the various specifications) and is even somewhat lower when using LITERACY as an indicator of human capital levels. Hence, the partial correlations are well below the critical value of 0.8 often suggested in the econometric literature. Moreover, we do not find the classical symptom for multicollinearity, i.e. high $\mathrm{R}^{2}$ in combination with low t-ratios, in the estimation of equation (8). Hence, we believe that the results are not affected by multicollinearity between GDP per capita and human capital levels.
} 
established in the regression using time dummies only together with SCHOOL. Here, we find the overall effect of child labour on FDI to be -0.0432 or -0.40 per cent. With -0.1763 or -1.61 per cent the largest negative impact is implied by the estimation including country specific fixed effects and using CHILD2 as an indicator of child labour. One should, however, treat this result with some caution given that the small number of time-series observations might lead to imprecise coefficient estimates, in particular in the fixed effects regression.

\section{Conclusion}

In this paper, we shed light on the connection between child labour and foreign direct investment. Theoretically, there are various channels through which the former can influence the latter. On the one hand, child labour can depress wage shares in an economy thereby attracting investors seeking for countries with low labour costs (relative to productivity). On the other hand, potentially negative linkages exist. The suspected adverse human capital effect of child labour is likely to discourage FDI inflows. Investors might not find a skilled labour force in countries with severe child labour problems. Low human capital formation also impedes the economic development of a country. Market-seeking FDI is therefore less likely to flow into countries with high levels of child labour. Using panel data we find strong evidence for the hypothesis that child labour deters FDI by slowing down the economic development of a country. Some evidence is found for our theoretical predication that child labour can discourage FDI via its impact on the availability of a skilled labour force in an economy. However, the finding does only apply to high skill levels, and is even reversed at very low levels. Moreover, it is not robust across all specifications. Finally, the data does not indicate that high levels of child labour drive down the factor share of labour, thereby increasing the attractiveness of a country for foreign investors.

In conclusion, our study adds to the evidence against the view that investors favour countries with weak child labour standards. As previous studies, such as Kucera (2002) and Busse and Braun 
(2004), do also not find such evidence, the burden of proof ought to shift to those arguing the case in favour of a positive link between child labour and FDI.

\section{References}

Asiedu, E. (2002). On the Determinants of Foreign Direct Investment to Developing Countries: Is Africa Different? World Development 30(1):107-119.

Anker, R., S. Barge, S. Rajagopal, and M.P. Joseph (1998). Economics of Child Labour in Hazardous Industries of India. Hindustan Publishers, New Dehli.

Bachman, S.L. (2000). New Economics of Child Labor: Searching for Answers Behind the Headlines. Journal of International Affairs 53(2):545-572.

Barro, R.J. (1991). Economic Growth in a Cross Section of Countries. The Quarterly Journal of Economics 106(2):407-443.

Barro, R.J. (2001). Human Capital and Growth. American Economic Review 91(2):12-17.

Barro, R.J. and J.-W. Lee (2000). International Data on Educational Attainment: Updates and Implications. CID Working Paper 42.

Bartel, A.P. and F. Lichtenberg (1987). The Comparative Advantage of Educated Workers in Implementing New Technology: Some Empirical Evidence. Review of Economics and Statistics 69(1): 1-11.

Basu, K. (1999). Child Labor: Cause, Consequence, and Cure, with Remarks on International Labor Standards. Journal of Economic Literature 37(3):1083-1119.

Basu, K. and Z. Tzannatos (2003). The Global Child Labor Problem: What do We Know and What Can We Do? The World Bank Economic Review 17(2):147-73.

Basu, K. and P.H. Van (1998). The Economics of Child Labor. American Economic Review 88(3):412-27.

Billington, N. (1999). The Location of Foreign Direct Investment: an Empirical Analysis. Applied Economics 31(1):65-76.

Busse, M. and S. Braun (2004). Export Structure, FDI and Child Labour. Journal of Economic Integration 19(4):804-829.

Caselli, F (2005). Accounting for Cross-Country Income Differences. In Aghion, P. and S.N. Durlauf (eds.), Handbook of Economic Growth, vol. 1, Part A. North-Holland: Elsevier, Amsterdam.

Carstensen, K. and F. Toubal (2004). Foreign Direct Investment in Central and Eastern European Countries: A Dynamic Panel Analysis. Journal of Comparative Economics 32(1):3-22. 
Chakrabarti, A. (2001). The Determinants of Foreign Direct Investment: Sensitivity Analyses of Cross-Country Regressions. Kyklos 54(1):89-113.

Daude, C., A. Morrison and J. Mazza (2003). Core Labor Standards and FDI in Latin America and the Carribean: Does Lax Enforcement of Labor Standards Attract Investors? Inter-American Development Bank.

Emerson, P. and A. Souza (2004). Is Child Labor Harmful? The Effect of Working as a Child on Adult Earnings. Working Paper, University of Colorado, Department of Economics.

Freedom House (2004). Freedom in the World: The Annual Survey of Political Rights and Civil Liberties 2002-03. Transaction Publications, New Brunswick.

Harms, P. and Ursprung, H (2002). Do Civil and Political Repression Really Boost Foreign Direct Investment? Economic Inquiry 40(4):651-663.

Hatem, F. (1997). International Investment: Towards the Year 2001. United Nations, New York.

Helliwell, J. (1994). Empirical Linkages Between Democracy and Economic Growth. British Journal of Political Science 24:225-248.

Heston A., R. Summers and B. Aten (2002), Penn World Table Version 6.1, Center for International Comparisons at the University of Pennsylvania (CICUP).

Hussain, M. and K.E. Maskus (2003). Child Labour Use and Economic Growth: an Econometric Analysis. The World Economy 26(7):993-1017.

ILO (1998). Declaration on Fundamental Principles and Rights at Work and its Follow-up. ILO, Geneva.

ILO (2002). A Future Without Child Labour. International Labour Conference 90th Session. ILO, Geneva, Report I (B).

Kucera, D. (2001). The Effects of Core Workers Rights on Labour Costs and Foreign Direct Investment: Evaluating the "Conventional Wisdom". IILS Decent Work Research Programme Working Paper No. 130. IILS, Geneva.

Kucera, D. (2002). Core Labour Standards and Foreign Direct Investment. International Labour Review 141(1/2):31-69.

Lim, D. (1983). Fiscal Incentives and Direct Foreign Investment in Less Developed Countries. The Journal of Development Studies 19(2):207-212.

OECD (1996). Trade, Employment and Labour Standards: A Study of Core Workers' Rights and International Trade. OECD, Paris.

OECD (2000). International Trade and Core Labour Standards. OECD, Paris.

Palley, T. (2002). The Child Labor Problem and the Need for International Labor Standards. Journal of Economic Issues 36(3):601-615.

Rama, R. and R. Artecona (2002). A Database of Labor Market Indicators Across Countries. unpublished. World Bank, Washington. 
Rao, K.H. and N.M. Rao (1998). Employers' View of Child Labour. Indian Journal of Industrial Relations 34(1):15-38.

Rodrik, D. (1996). Labor Standards in International Trade: Do They Matter and What Do We Do About Them? In Lawrence, R.Z., D. Rodrik and J. Whalley (eds.), Emerging Agenda for Global Trade: High States for Developing Countries. Johns Hopkins University Press, Baltimore.

Rodrik, D. (1999). Democracies Pay Higher Wages. The Quarterly Journal of Economics 114(3):707-738.

Schneider, F. and B. Frey (1985). Economic and Political Determinants of Foreign Direct Investment. World Development 13(2):161-175.

Tsai, P.L. (1994). Determinants of Foreign Direct Investment and its Impact on Economic Growth. Journal of Economic Development 19(1):137-163.

UNCTAD. (2003). FDI in Landlocked Developing Countries at a Glance. United Nations, New York and Geneva.

UNCTAD. (2005). World Investment Report 2005. United Nations, New York and Geneva.

Wheeler, D. A. and Moody. (1992). International Investment Decisions: The Case of US Firms. Journal of International Economics 33(1):57-76.

World Bank (2004). World Development Indicators. World Bank, Washington. 


\section{Figures and Tables}

Figure 1: Theoretical Effects of Child Labour on FDI

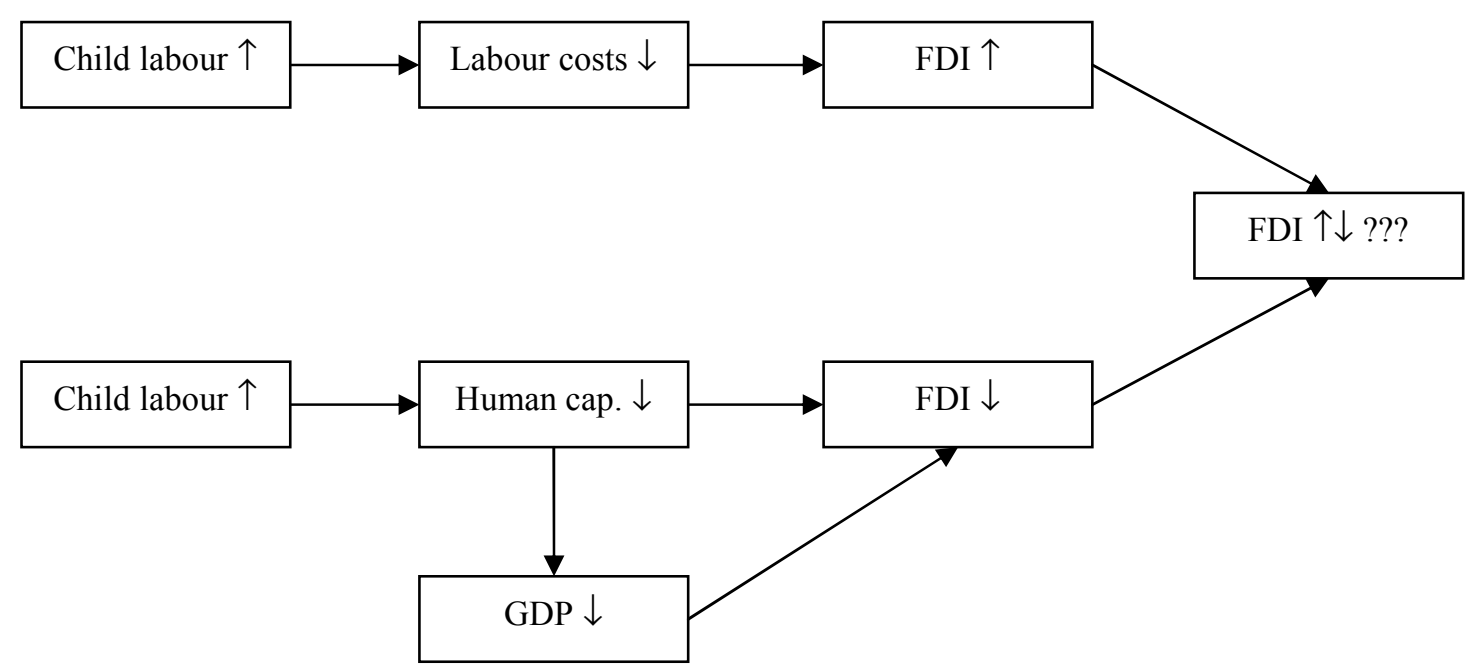

Table 1: Country Sample

\begin{tabular}{llll}
\hline Country & Continent & Country & Continent \\
\hline Albania & Europe & Mali & Africa \\
Argentina & South America & Mauritius & Africa \\
Bangladesh & Asia & Mexico & North \& Central America \\
Bolivia & South America & Morocco & Africa \\
Botswana & Africa & Nepal & Asia \\
Brazil & South America & Nicaragua & North \& Central America \\
Burkina Faso & Africa & Niger & Africa \\
Chile & South America & Nigeria & Africa \\
China & Asia & Pakistan & Asia \\
Colombia & South America & Panama & North \& Central America \\
Costa Rica & North \& Central America & Papua New Guinea & Oceania \\
Dominican Republic & North \& Central America & Paraguay & South America \\
Ecuador & South America & Peru & South America \\
Egypt, Arab Republic. & Africa & Philippines & Asia \\
El Salvador & North \& Central America & Romania & Europe \\
Ethiopia & Africa & Rwanda & Africa \\
Ghana & Africa & Senegal & Africa \\
Guatemala & North \& Central America & Sierra Leone & Africa \\
Honduras & North \& Central America & South Africa & Africa \\
India & Asia & Sri Lanka & Asia \\
Indonesia & Asia & Syrian Arab Republic & Asia \\
Iran, Islamic Republic & Asia & Thailand & Asia \\
Ivory Coast & Africa & Tunisia & Africa \\
Jamaica & North \& Central America & Turkey & Asia \\
Jordan & Asia & Uruguay & South America \\
Kenya & Africa & Venezuela & South America \\
Lesotho & Africa & Zambia & Africa \\
Malaysia & Asia & Zimbabwe & Africa \\
\hline
\end{tabular}


Table 2: Definition of Variables and Data Sources

\begin{tabular}{|c|c|c|}
\hline Variable & Definition & Source \\
\hline CAPWOK & $\begin{array}{l}\text { Physical capital per worker in international } \\
\text { dollars (PPP-adjusted) }\end{array}$ & $\begin{array}{l}\text { Heston et al. (2002), own } \\
\text { calculations }\end{array}$ \\
\hline CHILD & $\begin{array}{l}\text { Labour force participation rate of children aged } \\
10-14\end{array}$ & World Bank (2004) \\
\hline FDI & FDI per capita, net inflows in current US dollars & World Bank (2004) \\
\hline GDP & $\begin{array}{l}\text { GDP per capita in international dollars (PPP- } \\
\text { adjusted) in current prices }\end{array}$ & Heston et al. (2002) \\
\hline GROWTH & Real growth of GDP per capita in per cent & World Bank (2004) \\
\hline HUMAN & $\begin{array}{l}\text { Average schooling years in total population over } \\
\text { age } 15\end{array}$ & Barro and Lee (2000) \\
\hline LLDC & $\begin{array}{l}\text { Dummy variable that takes on a value of one if a } \\
\text { country is landlocked }\end{array}$ & UNCTAD (2003) \\
\hline OPEN & $\begin{array}{l}\text { Ratio of total exports and imports divided by } \\
\text { GDP }\end{array}$ & World Bank (2004) \\
\hline QUALITY & Pupil-teacher ratio in primary schools & World Bank (2004) \\
\hline URBAN & $\begin{array}{l}\text { Share of the total population living in areas } \\
\text { defined as urban (in per cent) }\end{array}$ & World Bank (2004) \\
\hline PRICES & Price level of consumption & Heston et al. (2002) \\
\hline RISK & $\begin{array}{l}\text { Index for political rights and civil liberties, } \\
\text { ranging from } 0 \text { to } 1\end{array}$ & Freedom House (2004) \\
\hline SCHOOL & $\begin{array}{l}\text { Gross secondary school non-enrolment rate in } \\
\text { per cent }\end{array}$ & World Bank (2004) \\
\hline STABILITY & $\begin{array}{l}\text { Inflation rate, calculated as the percentage } \\
\text { change of the GDP deflator }\end{array}$ & World Bank (2004) \\
\hline LITERACY & $\begin{array}{l}\text { Percentage of people ages } 15 \text { and above who can, } \\
\text { with understanding, read and write a short, } \\
\text { simple statement on their everyday life }\end{array}$ & World Bank (2004) \\
\hline WVA & $\begin{array}{l}\text { Ratio between wage cost and value added per } \\
\text { worker in the manufacturing sector }\end{array}$ & $\begin{array}{l}\text { Rama and Artecona (2002), own } \\
\text { calculations }\end{array}$ \\
\hline
\end{tabular}

Table 3: Descriptive Statistics

\begin{tabular}{lccccc}
\hline & Mean & Median & Maximum & Minimum & Std. Dev. \\
\hline CAPWOK & 7937 & 5148 & 34029 & 172.1 & 7368 \\
CHILD1 & 18.21 & 16.22 & 62.49 & .0000 & 14.01 \\
CHILD2 & 18.65 & 16.24 & 62.23 & .0000 & 14.27 \\
FDI & 10.92 & 3.879 & 91.71 & -14.39 & 17.56 \\
GDP & 2296 & 1826 & 9301 & 250.6 & 1780 \\
GROWTH & 1.650 & 1.557 & 15.82 & -7.265 & 3.419 \\
HUMAN & 3.966 & 3.874 & 9.432 & .3680 & 1.728 \\
LITERACY & 63.77 & 69.90 & 97.29 & 7.212 & 23.90 \\
OPENESS & 53.21 & 47.14 & 138.6 & 8.917 & 29.26 \\
QUALITY & 33.41 & 32.04 & 63.00 & 13.81 & 8.889 \\
PRICES & 49.35 & 43.18 & 259.2 & 19.79 & 27.87 \\
RISK & .5837 & .6000 & 1.000 & .1429 & .2131 \\
SCHOOL & 61.58 & 61.94 & 96.93 & 16.45 & 19.16 \\
STABILITY & 47.88 & 12.12 & 1626 & -6.105 & 158.9 \\
URBAN & 41.52 & 40.40 & 89.60 & 4.282 & .079 \\
WVA & .2869 & .2667 & & .5442 & .0704 \\
\hline
\end{tabular}


Table 4: 3SLS Estimation Results

\begin{tabular}{|c|c|c|c|c|c|}
\hline \multirow{2}{*}{$\begin{array}{l}\text { Independent } \\
\text { variable }\end{array}$} & \multicolumn{5}{|c|}{ Dependent variable } \\
\hline & $\begin{array}{c}\text { CHILD } \\
(1)\end{array}$ & $\begin{array}{c}\text { HUMAN } \\
(2)\end{array}$ & $\begin{array}{c}\text { GDP } \\
(3)\end{array}$ & $\begin{array}{l}\text { WVA } \\
(4) \\
\end{array}$ & $\begin{array}{c}\text { FDI } \\
(5)\end{array}$ \\
\hline CAPWOK & & & $\begin{array}{l}.1808 * * * \\
(.0099)\end{array}$ & & \\
\hline CHILD2(-1) & & $\begin{array}{c}-.0064 * * * \\
(.0022)\end{array}$ & & $\begin{array}{c}.0002 \\
(.0007)\end{array}$ & \\
\hline GDP & & & & $\begin{array}{l}.0000^{* *} \\
(.0000)\end{array}$ & $\begin{array}{c}.0044 * * * \\
(.0013)\end{array}$ \\
\hline GROWTH & & & & & $\begin{array}{c}1.199 * * * \\
(.3899)\end{array}$ \\
\hline HUMAN & & & $\begin{array}{c}85.61 * * \\
(43.74)\end{array}$ & & $\begin{array}{l}-2.877 \\
(3.255)\end{array}$ \\
\hline$(\text { HUMAN })^{2}$ & & & & & $\begin{array}{l}.4533 \\
(.3286)\end{array}$ \\
\hline HUMAN(-1) & & $\begin{array}{c}.9675 * * * \\
(.0227)\end{array}$ & & & \\
\hline $\log (\mathrm{HUMAN}(-1))$ & $\begin{array}{c}-17.25 * * * \\
(1.218)\end{array}$ & & & & \\
\hline LLDC & & & & & $\begin{array}{c}1.468 \\
(3.958)\end{array}$ \\
\hline OPEN & & & & & $\begin{array}{l}.1327 * * \\
(.0676)\end{array}$ \\
\hline PRICES & & & & $\begin{array}{l}.0003 \\
(.0003)\end{array}$ & \\
\hline QUALITY & $\begin{array}{l}.1991 * * \\
(.0821)\end{array}$ & $\begin{array}{l}-.0038 \\
(.0030)\end{array}$ & & & \\
\hline RISK & & & & & $\begin{array}{c}-10.53 \\
(7.169)\end{array}$ \\
\hline STABILITY & & & & & $\begin{array}{l}-.0029 \\
(.0088)\end{array}$ \\
\hline URBAN & & & & $\begin{array}{c}-.0019 * * * \\
(.0007)\end{array}$ & \\
\hline WVA & & & & & $\begin{array}{c}59.65 \\
(58.35)\end{array}$ \\
\hline Time Dummies & Yes & Yes & Yes & Yes & Yes \\
\hline $\mathrm{R}^{2}$ & .6607 & .9722 & .8434 & .0707 & .3443 \\
\hline Observations & 175 & 175 & 175 & 175 & 175 \\
\hline
\end{tabular}


Table 5: Effects on FDI of an Increase in the Child Labour Variable by One Per Cent

\begin{tabular}{|c|c|c|c|c|c|c|c|c|c|c|c|}
\hline \multicolumn{4}{|c|}{ Specification } & \multicolumn{7}{|c|}{ Intermediate effects } & \multirow[b]{2}{*}{$\begin{array}{c}\text { Overal } \\
\text { impact } \\
\text { on FDI } \\
(12)\end{array}$} \\
\hline $\begin{array}{l}\text { Human } \\
\text { capital } \\
\text { variable } \\
\text { (1) }\end{array}$ & $\begin{array}{l}\text { Child } \\
\text { labour } \\
\text { variable } \\
(2)\end{array}$ & $\begin{array}{c}\text { Cross - } \\
\text { sectional } \\
\text { dummies } \\
\text { (3) }\end{array}$ & $\begin{array}{c}\text { Time } \\
\text { dummies } \\
\text { (4) }\end{array}$ & $\begin{array}{c}\mathrm{CL}^{\mathrm{a}} \Rightarrow \\
\mathrm{HC}^{\mathrm{b}} \\
\text { effect } \\
(5)\end{array}$ & $\begin{array}{c}\mathrm{CL}^{\mathrm{a}} \Rightarrow \\
\text { WVA } \\
\text { effect } \\
(6)\end{array}$ & $\begin{array}{c}\mathrm{HC}^{\mathrm{b}} \Rightarrow \\
\text { GDP } \\
\text { effect } \\
(7)\end{array}$ & $\begin{array}{c}\text { WVA } \Rightarrow \\
\text { FDI } \\
\text { effect } \\
(8)\end{array}$ & $\begin{array}{c}\mathrm{HC}^{\mathrm{b}} \Rightarrow \\
\text { FDI } \\
\text { effect } \\
(9)\end{array}$ & $\begin{array}{c}\left(\mathrm{HC}^{\mathrm{b}}\right)^{2} \Rightarrow \\
\text { FDI } \\
\text { effect } \\
(10)\end{array}$ & $\begin{array}{c}\mathrm{GDP} \Rightarrow \\
\text { FDI } \\
\text { effect } \\
(11)\end{array}$ & \\
\hline HUMAN & CHILD1 & No & Yes & $\begin{array}{c}-.0152 * * * \\
(.0046)\end{array}$ & $\begin{array}{c}.0003 \\
(.0009)\end{array}$ & $\begin{array}{c}79.92 \\
(66.00)\end{array}$ & $\begin{array}{c}41.27 \\
(74.30)\end{array}$ & $\begin{array}{c}-6.791 \\
(4.968)\end{array}$ & $\begin{array}{l}.9334^{*} \\
(.4794)\end{array}$ & $\begin{array}{c}.0049 * * * \\
(.0018)\end{array}$ & -.1125 \\
\hline HUMAN & CHILD2 & No & Yes & $\begin{array}{c}-.0064 * * * \\
(.0022)\end{array}$ & $\begin{array}{c}.0002 \\
(.0007)\end{array}$ & $\begin{array}{c}85.61 * * \\
(43.74)\end{array}$ & $\begin{array}{c}59.65 \\
(58.35)\end{array}$ & $\begin{array}{l}-2.877 \\
(3.255)\end{array}$ & $\begin{array}{c}.4533 \\
(.3286)\end{array}$ & $\begin{array}{c}.0044 * * * \\
(.0013)\end{array}$ & -.0024 \\
\hline HUMAN & SCHOOL & No & Yes & $\begin{array}{c}-.0088^{* * *} \\
(.0024)\end{array}$ & $\begin{array}{l}-.0004 \\
(.0006)\end{array}$ & $\begin{array}{l}83.40^{*} \\
(50.17)\end{array}$ & $\begin{array}{c}-12.24 \\
(40.10)\end{array}$ & $\begin{array}{l}-4.421 \\
(3.115)\end{array}$ & $\begin{array}{l}.5609^{*} \\
(.3409)\end{array}$ & $\begin{array}{c}.0055^{* * *} \\
(.0012)\end{array}$ & -.0432 \\
\hline HUMAN & CHILD1 & Continent & No & $\begin{array}{c}-.0178^{* * *} \\
(.0049)\end{array}$ & $\begin{array}{l}-.0000 \\
(.0010)\end{array}$ & $\begin{array}{c}264.9 * * * \\
(73.15)\end{array}$ & $\begin{array}{c}142.2 \\
(156.8)\end{array}$ & $\begin{array}{c}-9.277 * * \\
(4.720)\end{array}$ & $\begin{array}{l}1.357 * * \\
(.5397)\end{array}$ & $\begin{array}{c}.0033 \\
(.0021)\end{array}$ & -.0265 \\
\hline HUMAN & CHILD2 & Continent & No & $\begin{array}{c}-.0078 * * * \\
(.0023)\end{array}$ & $\begin{array}{l}-.0000 \\
(.0008)\end{array}$ & $\begin{array}{c}218.6 * * * \\
(48.84)\end{array}$ & $\begin{array}{l}-24.82 \\
(92.64)\end{array}$ & $\begin{array}{l}-5.080 \\
(3.124)\end{array}$ & $\begin{array}{c}.6975 \\
(.4596)\end{array}$ & $\begin{array}{l}.0045^{* *} \\
(.0018)\end{array}$ & -.0077 \\
\hline HUMAN & SCHOOL & Continent & No & $\begin{array}{c}-.0082 * * * \\
(.0025)\end{array}$ & $\begin{array}{l}-.0005 \\
(.0007)\end{array}$ & $\begin{array}{c}205.5 * * * \\
(55.36)\end{array}$ & $\begin{array}{c}57.88 \\
(72.94)\end{array}$ & $\begin{array}{l}-5.520 \\
(3.437)\end{array}$ & $\begin{array}{l}.8902 * * \\
(.4383)\end{array}$ & $\begin{array}{l}.0037 * * \\
(.0015)\end{array}$ & -.0641 \\
\hline HUMAN & CHILD2 & Country & No & $\begin{array}{c}-.0409 * * * \\
(.0109)\end{array}$ & $\begin{array}{l}.0028 \\
(.0023)\end{array}$ & $\begin{array}{c}463.5 * * * \\
(67.62)\end{array}$ & $\begin{array}{c}14.38 \\
(81.23)\end{array}$ & $\begin{array}{l}-4.762 \\
(6.737)\end{array}$ & $\begin{array}{l}.1705 \\
(.8496)\end{array}$ & $\begin{array}{c}.0093 * * * \\
(.0023)\end{array}$ & -.1763 \\
\hline HUMAN & SCHOOL & Country & No & $\begin{array}{c}-.0140 * * * \\
(.0040)\end{array}$ & $\begin{array}{c}.0011 \\
(.0008)\end{array}$ & $\begin{array}{c}390.9 * * * \\
(98.50)\end{array}$ & $\begin{array}{c}3.724 \\
(89.66)\end{array}$ & $\begin{array}{c}-8.696 \\
(11.50)\end{array}$ & $\begin{array}{c}.9103 \\
(1.263)\end{array}$ & $\begin{array}{c}.0059 * * * \\
(.0022)\end{array}$ & -.0323 \\
\hline HUMAN & CHILD1 & Continent & Yes & $\begin{array}{c}-.0183 * * * \\
(.0048)\end{array}$ & $\begin{array}{l}-.0002 \\
(.0010)\end{array}$ & $\begin{array}{l}161.7 * * \\
(73.20)\end{array}$ & $\begin{array}{c}81.86 \\
(128.6)\end{array}$ & $\begin{array}{c}-10.27 * * \\
(4.427)\end{array}$ & $\begin{array}{c}1.481 * * * \\
(.5158)\end{array}$ & $\begin{array}{c}.0029 \\
(.0023)\end{array}$ & -.0270 \\
\hline HUMAN & CHILD2 & Continent & Yes & $\begin{array}{c}-.0081 * * * \\
(.0023)\end{array}$ & $\begin{array}{l}-.0004 \\
(.0008)\end{array}$ & $\begin{array}{c}132.4 * * * \\
(47.71)\end{array}$ & $\begin{array}{c}77.66 \\
(152.0)\end{array}$ & $\begin{array}{l}-5.864 * \\
(3.463)\end{array}$ & $\begin{array}{c}.8491 \\
(.5411)\end{array}$ & $\begin{array}{c}.0026 \\
(.0036)\end{array}$ & .0475 \\
\hline HUMAN & SCHOOL & Continent & Yes & $\begin{array}{c}-.0083^{* * *} \\
(.0026)\end{array}$ & $\begin{array}{l}-.0008 \\
(.0007)\end{array}$ & $\begin{array}{l}128.9 * * \\
(54.97)\end{array}$ & $\begin{array}{c}1.340 \\
(59.93)\end{array}$ & $\begin{array}{l}-4.449 \\
(3.442)\end{array}$ & $\begin{array}{l}.7086^{*} \\
(.4161)\end{array}$ & $\begin{array}{c}.0049 * * * \\
(.0016)\end{array}$ & -.0519 \\
\hline LITERACY & CHILD1 & Continent & Yes & $\begin{array}{c}-.1049 * * * \\
(.0317)\end{array}$ & $\begin{array}{l}-.0014 \\
(.0010)\end{array}$ & $\begin{array}{c}17.65 * * * \\
(6.059)\end{array}$ & $\begin{array}{l}-244.9 \\
(162.7)\end{array}$ & $\begin{array}{l}.4467 \\
(.8522)\end{array}$ & $\begin{array}{l}-.0068 \\
(.0090)\end{array}$ & $\begin{array}{c}.0097 * * * \\
(.0031)\end{array}$ & -.0179 \\
\hline LITERACY & CHILD2 & Continent & Yes & $\begin{array}{c}-.0656 * * * \\
(.0120)\end{array}$ & $\begin{array}{l}-.0011 \\
(.0007)\end{array}$ & $\begin{array}{c}12.04 * * * \\
(3.604)\end{array}$ & $\begin{array}{l}-61.55 \\
(150.2)\end{array}$ & $\begin{array}{l}-.0173 \\
(.7182)\end{array}$ & $\begin{array}{c}.0002 \\
(.0081)\end{array}$ & $\begin{array}{c}.0074 \\
(.0049)\end{array}$ & .0000 \\
\hline LITERACY & SCHOOL & Continent & Yes & $\begin{array}{c}.0048 \\
(.0114)\end{array}$ & $\begin{array}{l}-.0011 * \\
(.0006)\end{array}$ & $\begin{array}{c}9.766^{* * * *} \\
(3.633)\end{array}$ & $\begin{array}{c}101.1 \\
(73.29)\end{array}$ & $\begin{array}{l}-.2692 \\
(.3598)\end{array}$ & $\begin{array}{c}.0020 \\
(.0039)\end{array}$ & $\begin{array}{l}.0040^{*} \\
(.0022)\end{array}$ & .0000 \\
\hline
\end{tabular}

${ }^{\mathrm{a}} \mathrm{CL}$ : Child Labour; ${ }^{\mathrm{b}} \mathrm{HC}$ : Human Capital; ${ }^{\mathrm{c}}$ only statistically significant values are taken into account, human capital effect is evaluated at the sample mean $*, * *, * * *$ significant at the level of 10, 5, and 1 per cent, respectively; Estimation by 3SLS; standard errors in parentheses 


\section{SFB 649 Discussion Paper Series 2006}

For a complete list of Discussion Papers published by the SFB 649, please visit http://sfb649.wiwi.hu-berlin.de.

001 "Calibration Risk for Exotic Options" by Kai Detlefsen and Wolfgang K. Härdle, January 2006.

002 "Calibration Design of Implied Volatility Surfaces" by Kai Detlefsen and Wolfgang K. Härdle, January 2006.

003 "On the Appropriateness of Inappropriate VaR Models" by Wolfgang Härdle, Zdeněk Hlávka and Gerhard Stahl, January 2006.

004 "Regional Labor Markets, Network Externalities and Migration: The Case of German Reunification" by Harald Uhlig, January/February 2006.

005 "British Interest Rate Convergence between the US and Europe: A Recursive Cointegration Analysis" by Enzo Weber, January 2006.

006 "A Combined Approach for Segment-Specific Analysis of Market Basket Data" by Yasemin Boztuğ and Thomas Reutterer, January 2006.

007 "Robust utility maximization in a stochastic factor model" by Daniel Hernández-Hernández and Alexander Schied, January 2006.

008 "Economic Growth of Agglomerations and Geographic Concentration of Industries - Evidence for Germany" by Kurt Geppert, Martin Gornig and Axel Werwatz, January 2006.

009 "Institutions, Bargaining Power and Labor Shares" by Benjamin Bental and Dominique Demougin, January 2006.

010 "Common Functional Principal Components" by Michal Benko, Wolfgang Härdle and Alois Kneip, Jauary 2006.

011 "VAR Modeling for Dynamic Semiparametric Factors of Volatility Strings" by Ralf Brüggemann, Wolfgang Härdle, Julius Mungo and Carsten Trenkler, February 2006.

012 "Bootstrapping Systems Cointegration Tests with a Prior Adjustment for Deterministic Terms" by Carsten Trenkler, February 2006.

013 "Penalties and Optimality in Financial Contracts: Taking Stock" by Michel A. Robe, Eva-Maria Steiger and Pierre-Armand Michel, February 2006.

014 "Core Labour Standards and FDI: Friends or Foes? The Case of Child Labour" by Sebastian Braun, February 2006.

SFB 649, Spandauer Straße 1, D-10178 Berlin

http:/ / sfb649.wiwi.hu-berlin.de 